\title{
Pengaruh Parameter Motor pada Sistem Kendali tanpa Sensor Putaran
}

\section{(Effect of Motor Parameters on Speed Sensorless Control System)}

\author{
Bernadeta Wuri Harini ${ }^{1}$
}

\begin{abstract}
In controlling a Permanent Magnet Synchronous Motor (PMSM) without using a speed sensor (sensorless control), some motor parameters are needed. Among the motor parameters used in the control are stator resistance, inductance, and magnetic flux. This paper analyzes the effect of these parameter values in sensorless motor control. The parameter values will be varied so that the motor parameter values in the current controller are different from the actual motor parameter values. The percentage of variation for each parameter varies depending on the influence of these parameters on control. The desired motor speed is $100 \mathrm{rad} / \mathrm{s}$ with the controlling constants $K_{P}=0.5$ and $K_{i}=0.9$. The controller gain values $\left(K_{P}\right.$ and $\left.K_{i}\right)$ are obtained by the heuristic tuning method. Simulations are carried out for several differences in parameter values using Simulink. Of the three parameters, the changes in the value of resistance and magnetic flux most affect the sensorless control system. The motor speed is different from the desired speed if the change in resistance value is $\geq 4 \%$ and magnetic flux is $\geq 10 \%$. The inductance values will have an effect if the change in inductance is very large, i.e., $L_{s d} \geq 500 \%$ and $L_{s q} \geq 300 \%$.
\end{abstract}

Intisari-Dalam pengendalian motor sinkron magnet permanen (Permanent Magnet Synchronous Motor/PMSM) tanpa menggunakan sensor putaran dibutuhkan beberapa data parameter motor. Di antara parameter motor yang digunakan dalam pengendalian tersebut adalah resistans dan induktans stator serta fluks magnetik. Pada makalah ini dianalisis pengaruh nilai-nilai parameter tersebut dalam pengendalian motor tanpa sensor putaran. Nilai-nilai parameter divariasikan sehingga nilai-nilai parameter motor yang ada di pengendali arus berbeda dengan nilai-nilai parameter motor yang sebenarnya. Besar persentase variasi masing-masing parameter berbeda-beda, tergantung pada pengaruh parameter tersebut terhadap pengendalian. Putaran motor yang diinginkan adalah $100 \mathrm{rad} / \mathrm{s}$ dengan pengaturan konstanta-konstanta pengendali $K_{P}$ $=0,5$ dan $K_{i}=0,9$. Nilai penguatan pengendali $\left(K_{P}\right.$ dan $\left.K_{i}\right)$ diperoleh dengan metode penalaan heuristic. Simulasi dilakukan untuk beberapa perbedaan nilai parameter menggunakan Simulink. Dari ketiga parameter tersebut, perubahan nilai resistans dan fluks magnetik paling memengaruhi sistem kendali. Putaran motor tidak sama dengan putaran yang diinginkan jika perubahan nilai resistans $\geq 4 \%$ dan fluks magnetik $\geq 10 \%$. Nilainilai induktans akan berpengaruh jika perubahan induktans sangat besar, yaitu $L_{s d} \geq \mathbf{5 0 0 \%}$ dan $L_{s q} \geq \mathbf{3 0 0 \%}$.

Kata Kunci- Fluks Magnetik, Induktans, Kendali tanpa Sensor Putaran, PMSM, Resistans.

${ }^{1}$ Jurusan Teknik Elektro, Fakultas Sains dan Teknologi, Universitas Sanata Dharma, Kampus III Paingan Maguwoharjo INDONESIA (e-mail: wuribernard@usd.ac.id)

\section{Pendahuluan}

Sistem kendali tanpa sensor putaran, atau yang sering disebut "sensorless control" adalah salah satu jenis pengendali yang sampai saat ini masih dikembangkan. Dalam sistem ini, nilai aktual sistem (controlled variable) tidak diukur langsung menggunakan sensor [1]. Nilai aktual tersebut diestimasi dari arus yang masuk ke plant menggunakan observer. Salah satu observer yang sudah banyak digunakan adalah Model Reference Adaptive System (MRAS), karena MRAS merupakan metode identifikasi putaran yang relatif matang [2]. Untuk plant berupa motor, nilai aktual keluaran motor diestimasi dari arus stator.

Dalam makalah ini, digunakan motor sinkron magnet permanen (Permanent Magnet Synchronous Motor/PMSM). PMSM merupakan sebuah motor sinkron tiga fase dengan rotor berupa magnet permanen dikelilingi stator berupa kumparan. PMSM banyak digunakan karena memiliki efisiensi, torka, daya, dan faktor daya yang tinggi, serta ukuran yang lebih kecil dan ringan. Di samping itu, PMSM mempunyai laju arus yang lebih rendah serta derau dan inersia getaran yang lebih rendah [3]. Jika torka motor DC dapat diatur dengan mengendalikan arus motor, tidak demikian dengan motor AC. Pada motor AC, baik sudut fase maupun modulo arus (yang berarti vektor arus) harus dikendalikan [1] Oleh karena itu, diperlukan kendali vektor. Dengan menggunakan kendali vektor, torka dan fluks yang menghasilkan arus di-decoupled sehingga dapat dikendalikan secara terpisah.

Kelebihan sistem pengendali ini adalah tidak diperlukannya sensor putaran yang dipasang pada motor. Penambahan sensor akan menambah biaya dan menimbulkan permasalahan pada saat pemasangan sensor [4]. Namun, dalam pengendalian ini diperlukan nilai-nilai parameter motor. Oleh karena itu, nilainilai parameter harus diketahui dengan baik agar pengendalian tanpa sensor putaran ini dapat beroperasi dengan baik. Pengukuran nilai parameter ini dapat dilakukan secara langsung menggunakan cara-cara pengukuran seperti yang dilakukan dalam penelitian sebelumnya, yang menjelaskan cara-cara pengukuran resistans dan induktans stator serta nilai konstanta back-EMF [5]. Di samping itu, pengukuran parameter dapat dilakukan secara tidak langsung (online). Oleh karena itu, banyak penelitian yang mengusulkan beberapa metode identifikasi nilai-nilai parameter [6]-[10]. Referensi [6] mengusulkan metode identifikasi parameter resistans dan induktans rotor pada interior PMSM (IPMSM) dan surface PMSM (SPMSM) yang tidak dipengaruhi oleh posisi atau putaran rotor. Sementara itu, dinyatakan juga 
bahwa pengukuran parameter resistans dan induktans rotor dipengaruhi oleh posisi rotor [7], [8]. Referensi [8] menegaskan bahwa parameter-parameter motor merupakan faktor yang penting dan sangat berpengaruh terhadap kinerja pengendalian motor. Referensi [9] mengusulkan metode identifikasi parameter resistans dan induktans sumbu $d q$ serta fluks secara offline dan online berdasarkan model impedans ekivalen frekuensi tinggi (High Frequency/HF) motor sinkron magnet permanen dengan injeksi sinyal HF pada kedua sumbu $d q$. Referensi [10] menggunakan metode Recursive Least Square (RLS) untuk mengidentifikasi nilai resistans dan induktans stator, sedangkan dalam penelitian lain telah dianalisis pengaruh parameter motor induksi dalam sistem pengendali putaran motor induksi [11]. Dalam makalah tersebut dijelaskan bahwa perbedaan nilai parameter akan menyebabkan kesalahan pada putaran motor.

Dalam penjelasan di atas dipaparkan bahwa parameter motor sangat penting dalam sistem kendali tanpa sensor putaran. Namun, dalam penelitian-penelitian tersebut tidak dijelaskan besar variasi nilai parameter motor yang memengaruhi pengendali putaran. Oleh karena itu, dalam makalah ini diteliti pengaruh perbedaan nilai parameter motor yang dikendalikan dengan sistem kendali tanpa sensor putaran (sensorless control) terhadap putaran motor. Berbeda dari penelitian sebelumnya, motor yang digunakan adalah PMSM empat pasang kutub [11]. Dari penelitian ini, dicari parameter motor PMSM yang sangat berpengaruh terhadap putaran motor. Parameter yang diteliti adalah parameter resistans dan induktans stator serta besar fluks magnetik.

\section{Sistem KENDALI PMSM TANPA SENSOR PUTARAN}

Diagram blok sistem kendali PMSM tanpa sensor putaran ditunjukkan pada Gbr. 1 [12]. Sistem ini terdiri atas bagianbagian sebagai berikut.

1) Pengendali Integral Proportional (IP): Bagian ini berfungsi sebagai pengendali putaran. Persamaan pengendali putaran IP ditunjukkan dalam (1).

$$
\begin{aligned}
i_{s q}^{*} & =\int K_{i}\left(\omega_{r}^{*}-\widehat{\omega}_{r}\right) d t-K_{p} \widehat{\omega}_{r} \\
& =K_{i} X_{w r}-K_{p} \widehat{\omega}_{r}
\end{aligned}
$$

dengan

$$
\begin{array}{ll}
i_{s q}^{*} & =\text { arus stator acuan pada sumbu } q(\mathrm{~A}) \\
\omega_{r}^{*} & =\text { putaran rotor acuan }(\mathrm{rad} / \text { detik }) \\
\widehat{\omega}_{r} & =\text { putaran rotor estimasi }(\mathrm{rad} / \mathrm{detik}) \\
K_{P}, K_{i} & =\text { penguatan pengendali putaran } \\
X_{w r} & =\text { integral kesalahan putaran }
\end{array}
$$

dengan

$$
\frac{d}{d t} X_{w r}=\left(\omega_{r}^{*}-\widehat{\omega}_{r}\right)
$$

2) Pengendali Proportional Integral (PI): Bagian ini berfungsi sebagai pengendali arus. Persamaan pengendali arus dinyatakan sebagai berikut.

$$
u_{s d}=K_{p d}\left(i_{s d}^{*}-i_{s d}\right)+K_{i d} \int\left(i_{s d}^{*}-i_{s d}\right) d t
$$

$$
u_{s q}=K_{p q}\left(i_{s q}^{*}-i_{s q}\right)+K_{i q} \int\left(i_{s q}^{*}-i_{s q}\right) d t
$$

dengan

$$
\begin{array}{ll}
i_{s d}^{*} & =\text { arus stator acuan pada sumbu } d(\mathrm{~A}) \\
i_{s d} & =\text { arus stator pada sumbu } d(\mathrm{~A}) \\
i_{s q} & =\text { arus stator pada sumbu } q(\mathrm{~A}) \\
K_{p d}, K_{p q} & =\text { penguatan proporsional dalam sumbu } d-q \\
K_{i d}, K_{i q} & =\text { penguatan integral dalam sumbu } d-q \\
U_{s d}, U_{s q} & =\text { arus keluaran pengendali arus }(\mathrm{A}) .
\end{array}
$$

3) Decoupling: Bagian decoupling berfungsi untuk menghilangkan cross coupling antara putaran dan arus yang tidak linier sehingga motor dapat dilihat sebagai sistem yang linier oleh pengendali. Persamaan decoupling adalah sebagai berikut [13].

$$
\begin{gathered}
V_{s d}=U_{s d}-N \hat{\omega}_{r} L_{s q} i_{s q 1} \\
V_{s q}=U_{s q}+N \hat{\omega}_{r} L_{s d} i_{s d 1}+N \hat{\omega}_{r} \psi_{F}
\end{gathered}
$$

dengan

$$
\begin{gathered}
\frac{d}{d t} i_{s d 1}=\frac{1}{T_{d}} i_{s d}^{*}-\frac{1}{T_{d}} i_{s d 1} \\
\frac{d}{d t} i_{s q 1}=\frac{1}{T_{d}} i_{s q}^{*}-\frac{1}{T_{d}} i_{s q 1}
\end{gathered}
$$

dengan

$$
\begin{array}{ll}
V_{s d} & =\text { tegangan stator dalam sumbu } d \\
V_{s q} & =\text { tegangan stator dalam sumbu } q \\
N & =\text { jumlah pasangan kutub } \\
L_{s d}, L_{s q} & =\text { induktans stator }(\mathrm{H}) \\
i_{s d 1}, i_{s q 1} & =\text { arus decoupling }(\mathrm{A}) .
\end{array}
$$

4) Observer Model Reference Adaptive System (MRAS): Bagian ini digunakan untuk memperkirakan variabel putaran yang dikendalikan [14]. Observer memperkirakan putaran rotor dari arus stator yang diukur dengan sensor arus dengan persamaan sebagai berikut.

$$
\begin{aligned}
& \hat{\omega}_{r}=\left(K_{w p}+\frac{K_{w r i}}{s}\right)\left(\frac{L_{s q}}{L_{s d}} i_{s d} \hat{i}_{s q}-\frac{L_{s d}}{L_{s q}} i_{s q} \hat{i}_{s d}-\frac{\psi_{F}}{L_{s q}}\left(i_{s q}-\hat{i}_{s q}\right)+\hat{i}_{s d}\right. \\
& \text { dengan } \\
& K_{w r p}=\text { penguatan proporsional MRAS } \\
& K_{w r i}=\text { penguatan integrator MRAS } \\
& \hat{\imath}_{s d}, \hat{\imath}_{s q}=\text { arus estimasi dalam sumbu } d-q \\
& \Psi_{F} \quad=\text { fluks magnetik (V.s/rad). }
\end{aligned}
$$

5) PMSM dengan Model Matematik: Bagian ini dijelaskan dalam persamaan sebagai berikut.

$$
\frac{d}{d t} i_{s d}=\frac{V_{s d}-R_{s} i_{s d}+N \omega_{r} L_{s q} i_{s q}}{L_{s d}}
$$




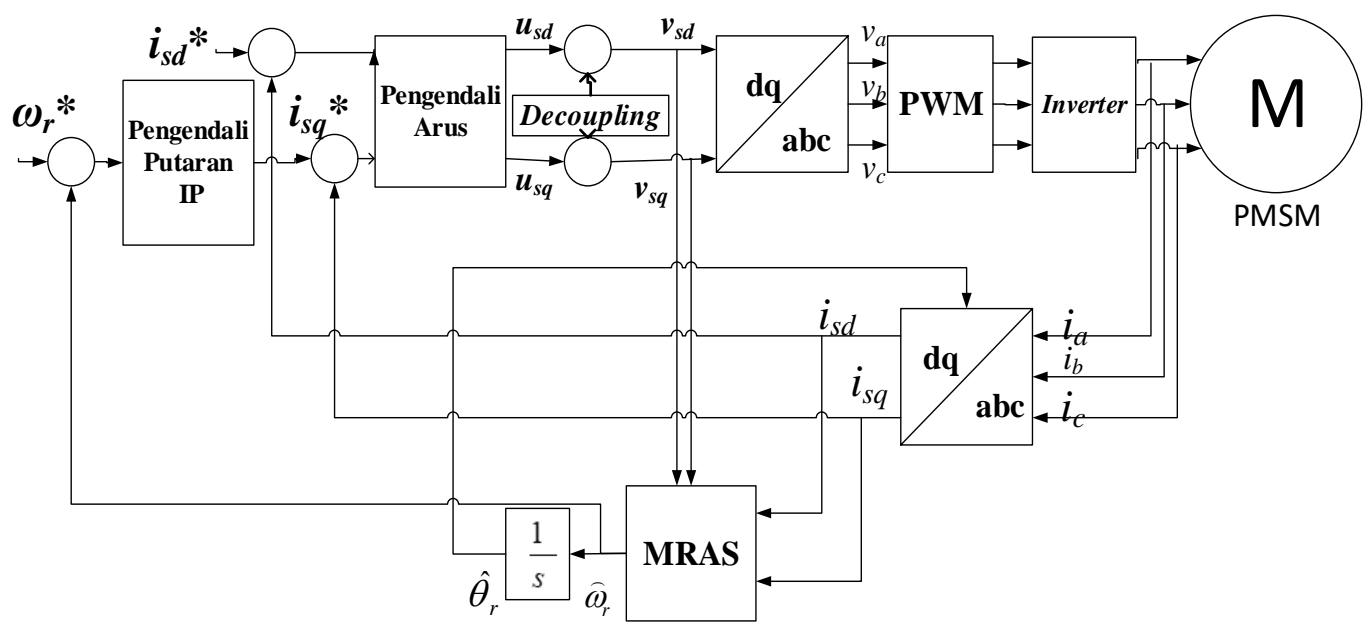

Gbr. 1 Diagram blok sistem kendali PMSM tanpa sensor putaran.

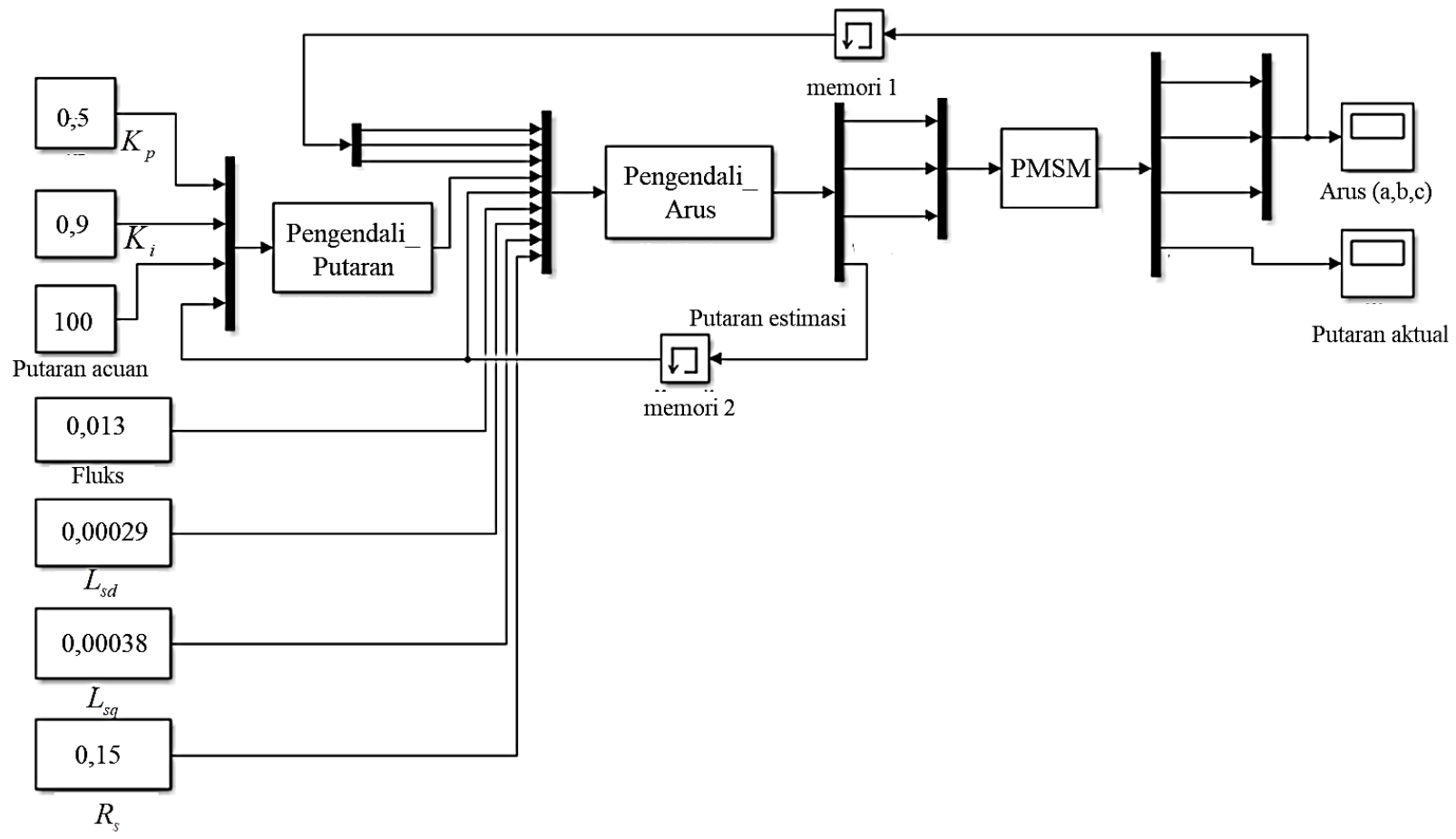

Gbr. 2 Diagram blok sistem pengujian.

$$
\frac{d}{d t} i_{s q}=\frac{V_{s q}-i_{s d} N \omega_{r} L_{s d}-R_{s} i_{s q}-N \omega_{r} \psi_{F}}{L_{s q}}
$$

dengan $R_{S}=$ resistans stator $(\Omega)$.

6) Pengubah Model Matematika Tiga Fase ke dalam Bentuk Matematika Dua Fase Menggunakan Transformasi Clarke Dan Park [15]: Transformasi Clarke mengubah persamaan tiga fase $\left(V_{s a}, V_{s b}, V_{s c}\right)$ menjadi persamaan dua fase stasioner $(\alpha, \beta, 0)$. Transformasi Park mengubah model PMSM dalam dua fase stasioner $(\alpha, \beta, 0)$ menjadi rotating reference $(d$, $q, 0)$ frame.

\section{METODOLOGI}

Pada makalah ini sistem kendali PMSM tanpa sensor putaran diuji dengan beberapa variasi parameter PMSM.
Nilai-nilai parameter yang digunakan ditunjukkan dalam Tabel I. Sistem diuji menggunakan Simulink. Diagram blok sistem pengujian ditunjukkan pada Gbr. 2. Dalam gambar tersebut, nilai-nilai parameter yang divariasi dimasukkan melalui bagian masukan. Variasi nilai parameter ditunjukkan pada Tabel II. Putaran yang diinginkan adalah $100 \mathrm{rad} / \mathrm{s}$ dengan pengaturan konstanta-konstanta pengendali $K_{P}=0,5$ dan $K_{i}=0,9$. Nilai penguatan pengendali $\left(K_{P}\right.$ dan $\left.K_{i}\right)$ diperoleh dengan metode penalaan heuristic [16]. Dalam prosedur penalaan heuristic terdapat aturan umum untuk mendapatkan hasil perkiraan atau kualitatif. Penguat yang disetel pertama adalah $K_{P}$, mulai dari nilai terendah sampai diperoleh tanggapan yang stabil. Apabila diperoleh tanggapan dengan kesalahan keadaan tunak, maka konstanta $K_{i}$ disetel. Untuk mendapatkan nilai yang diinginkan, dapat ditambahkan 
TABEL I

PARAMETER PMSM

\begin{tabular}{|c|c|c|l|}
\hline Parameter & Nilai & Satuan & \multicolumn{1}{|c|}{ Keterangan } \\
\hline$N$ & 4,000 & - & Jumlah pasangan kutub \\
\hline$R_{S}$ & 0,150 & $\Omega$ & Resistans stator \\
\hline$L_{s d}$ & 0,290 & $\mathrm{mH}$ & Induktans stator dalam sumbu $d$ \\
\hline$L_{s q}$ & 0,380 & $\mathrm{mH}$ & Induktans stator dalam sumbu $q$ \\
\hline$\Psi_{F}$ & 0,013 & V.s/rad & Fluks magnetik \\
\hline
\end{tabular}

TABEL II

VARIASI PARAMETER PMSM

\begin{tabular}{|c|c|c|c|}
\hline Parameter & Perubahan (\%) & Nilai & Satuan \\
\hline \multirow{3}{*}{$R_{s}$} & 3 & 0,15450 & \multirow{3}{*}{$\Omega$} \\
\cline { 2 - 3 } & 4 & 0,15600 & \\
\cline { 2 - 3 } & 5 & 0,15750 & \\
\hline \multirow{3}{*}{$L_{s d}$} & 300 & 1,20000 & \multirow{2}{*}{$\mathrm{mH}$} \\
\cline { 2 - 3 } & 500 & 1,50000 & \\
\cline { 2 - 3 } & 600 & 1,80000 & \\
\hline \multirow{3}{*}{$L_{s q}$} & 200 & 1,20000 & \multirow{2}{*}{$\mathrm{mH}$} \\
\cline { 2 - 3 } & 300 & 1,60000 & \\
\cline { 2 - 3 } & 500 & 2,00000 & \\
\hline \multirow{3}{*}{$\Psi_{F}$} & 5 & 0,01365 & \multirow{2}{*}{$\mathrm{V} . \mathrm{s} / \mathrm{rad}$} \\
\cline { 2 - 3 } & 10 & 0,01430 \\
\cline { 2 - 3 } & 15 & 0,01495 & \\
\hline
\end{tabular}

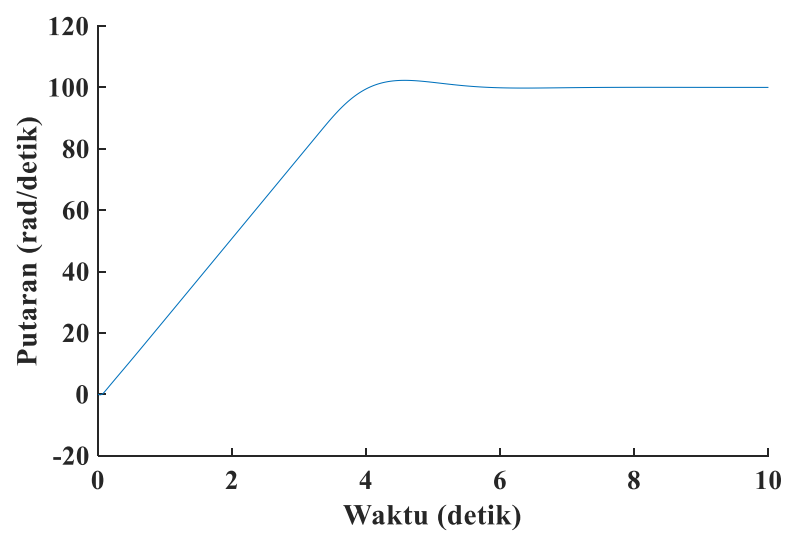

Gbr. 3 Putaran PMSM dengan nilai-nilai parameter motor pada pengendali arus adalah nilai-nilai parameter yang sebenarnya.

konstanta penguat diferensial sehingga diperoleh tanggapan yang optimum.

\section{HASIL DAN PEMBAHASAN}

Dengan memasukkan nilai-nilai parameter yang sebenarnya pada pengendali arus, keluaran pengendali ditunjukkan oleh Gbr. 3. Dalam Gbr. 3 tampak bahwa dengan nilai $K_{P}=0,5$ dan $K_{i}=0,9$, putaran motor mencapai nilai yang diinginkan, sebesar $100 \mathrm{rad} / \mathrm{s}$, dalam waktu settling time $T_{s}=5 \mathrm{~s}$. Lonjakan sistem ini kecil, yaitu sebesar 2,5\%.

Pada Gbr. 4 ditunjukkan putaran PMSM dengan nilai parameter $R_{S}$ motor pada pengendali arus divariasi. Pada Gbr. 4(a), parameter $R_{s}$ motor pada pengendali arus ditambah sebesar 3\% sehingga menjadi $0,1545 \Omega$. Tampak bahwa $T_{s}$ menjadi lebih lama, yaitu $5,5 \mathrm{~s}$, dengan lonjakan yang tetap. Pada tanggapan awal, tampak sedikit osilasi yang menunjukkan bahwa perubahan nilai resistans yang kecil ini

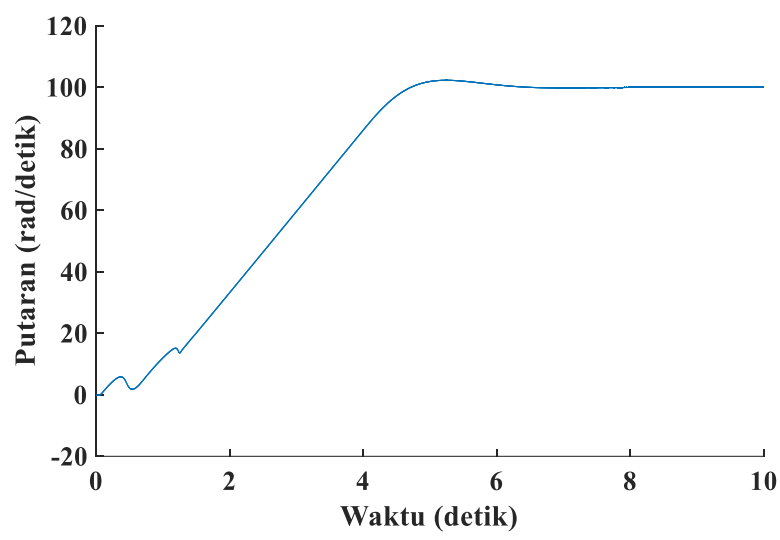

(a)

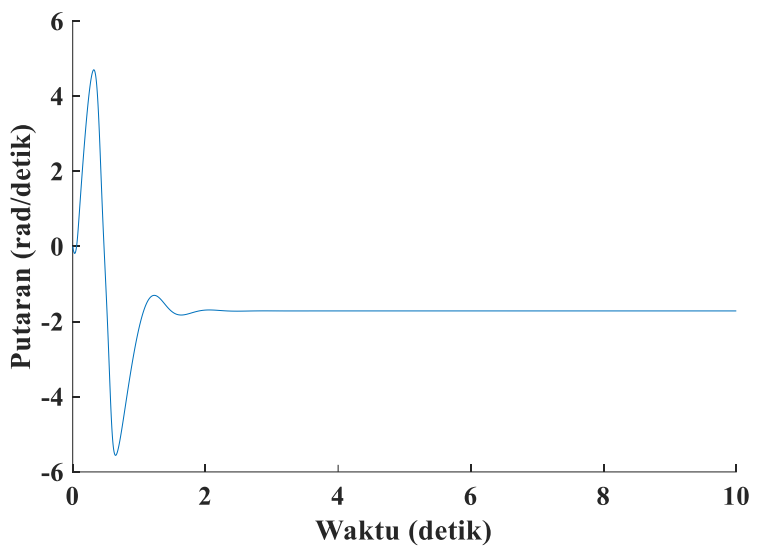

(b)

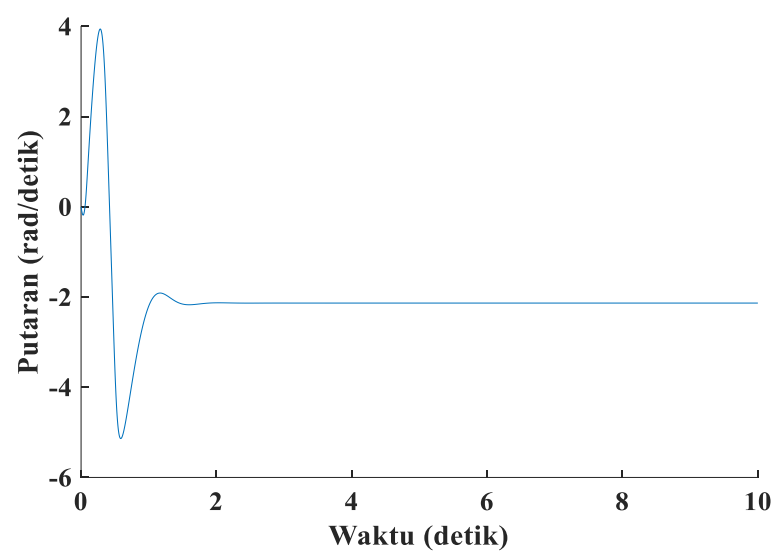

(c)

Gbr. 4 Putaran PMSM dengan nilai-nilai parameter $R_{s}$ motor pada pengendali arus divariasi, (a) perubahan $3 \%$, (b) perubahan $4 \%$, (c) perubahan $5 \%$.

juga memengaruhi kondisi transien motor. Pada Gbr. 4(b), parameter $R_{S}$ motor pada pengendali arus ditambah sebesar $4 \%$ sehingga menjadi $0,156 \Omega$, sedangkan pada Gbr. 4(c), parameter $R_{S}$ motor pada pengendali arus ditambah sebesar $5 \%$ sehingga menjadi $0,1575 \Omega$. Pada kedua gambar tersebut, terjadi lonjakan yang besar dan motor stabil pada kecepatan putar $-2 \mathrm{rad} / \mathrm{s}$, yang berarti motor berputar pada arah yang berlawanan. Pada kondisi ini telah terjadi kesalahan keadaan 
tunak sebesar $102 \%$. Hal ini menunjukkan bahwa perubahan nilai resistans yang kecil, yaitu delta resistans $\geq 4 \%$, menyebabkan tanggapan motor yang jauh dari yang ditentukan. Dengan demikian, parameter resistans ini sangat memengaruhi pengendalian tanpa sensor putaran. Hal ini menunjukkan bahwa pengukuran resistans motor harus tepat, sehingga dapat diperoleh nilai resistans yang sesuai dengan nilai yang sebenarnya.

Pada Gbr. 5 ditunjukkan putaran PMSM dengan nilai-nilai parameter $L_{s d}$ motor pada pengendali arus divariasi. Pada Gbr. 5(a), parameter $L_{s d}$ motor pada pengendali arus ditambah sebesar $300 \%$ sehingga menjadi 1,2 $\mathrm{mH}$. Tampak bahwa tanggapan sistem tidak mengalami perubahan, walaupun nilai $L_{s d}$ ditambah sebesar $300 \%$. Pada Gbr. 5(b), parameter $L_{s d}$ motor pada pengendali arus ditambah sebesar 500\% sehingga menjadi $1,5 \mathrm{mH}$. Tampak bahwa tanggapan dapat mencapai kondisi stabil, tetapi putaran motor tidak dapat mencapai nilai yang ditentukan. Putaran motor stabil pada putaran $60 \mathrm{rad} / \mathrm{s}$. Hal ini berarti telah terjadi kesalahan keadaan tunak sebesar $40 \%$. Apabila delta $L_{s d}$ ditambah, tanggapan motor menjadi semakin buruk, seperti yang ditunjukkan pada Gbr. 5(c). Pada gambar tersebut, parameter $L_{s d}$ motor pada pengendali arus ditambah sebesar $600 \%$ sehingga menjadi $1,8 \mathrm{mH}$. Tampak bahwa putaran motor menjadi tidak stabil pada putaran yang jauh dari nilai yang diinginkan. Putaran motor berosilasi di sekitar $40 \mathrm{rad} / \mathrm{s}$, yang seharusnya putaran motor yang diinginkan adalah $100 \mathrm{rad} / \mathrm{s}$. Dari pengujian ini tampak bahwa perubahan parameter $L_{s d}$ yang besar akan memengaruhi pengendalian putaran motor pada sistem pengendali tanpa sensor putaran.

Pada Gbr. 6 ditunjukkan putaran PMSM dengan nilai-nilai parameter $L_{s q}$ motor pada pengendali arus divariasi. Pada Gbr. 6(a), parameter $L_{s q}$ motor pada pengendali arus ditambah sebesar $200 \%$ sehingga menjadi 1,2 $\mathrm{mH}$. Tampak bahwa tanggapan sistem tidak mengalami perubahan, walaupun nilai $L_{s q}$ ditambah sebesar 200\%. Pada Gbr. 6(b), parameter $L_{s q}$ motor pada pengendali arus ditambah sebesar $300 \%$ sehingga menjadi 1,6 $\mathrm{mH}$. Tampak bahwa tanggapan tidak dapat mencapai nilai yang ditentukan. Putaran motor berosilasi pada putaran sekitar $95 \mathrm{rad} / \mathrm{s}$. Apabila delta $L_{s q}$ ditambah, tanggapan motor menjadi semakin buruk, seperti yang ditunjukkan pada Gbr. 6(c). Pada gambar tersebut, parameter $L_{s q}$ motor pada pengendali arus ditambah sebesar $500 \%$ sehingga menjadi $2 \mathrm{mH}$. Tampak bahwa putaran motor menjadi tidak stabil. Motor bergetar di sekitar putaran $0 \mathrm{rad} / \mathrm{s}$. Dari pengujian ini tampak bahwa perubahan parameter $L_{s q}$ yang besar juga akan memengaruhi pengendalian putaran motor pada sistem pengendali tanpa sensor putaran.

Pada Gbr. 7 ditunjukkan putaran PMSM dengan nilai-nilai parameter $\Psi_{F}$ motor pada pengendali arus divariasi. Pada Gbr. 7(a), parameter $\Psi_{F}$ motor pada pengendali arus ditambah sebesar 5\% sehingga menjadi 0,01365 V.s/rad. Tampak bahwa tanggapan sistem tidak mengalami perubahan walaupun di awal transien terjadi sedikit osilasi. Pada Gbr. 7(b), parameter $\Psi_{F}$ motor pada pengendali arus ditambah sebesar $10 \%$ sehingga menjadi 0,0143 V.s/rad. Tampak bahwa tanggapan tidak dapat mencapai nilai yang ditentukan. Putaran motor

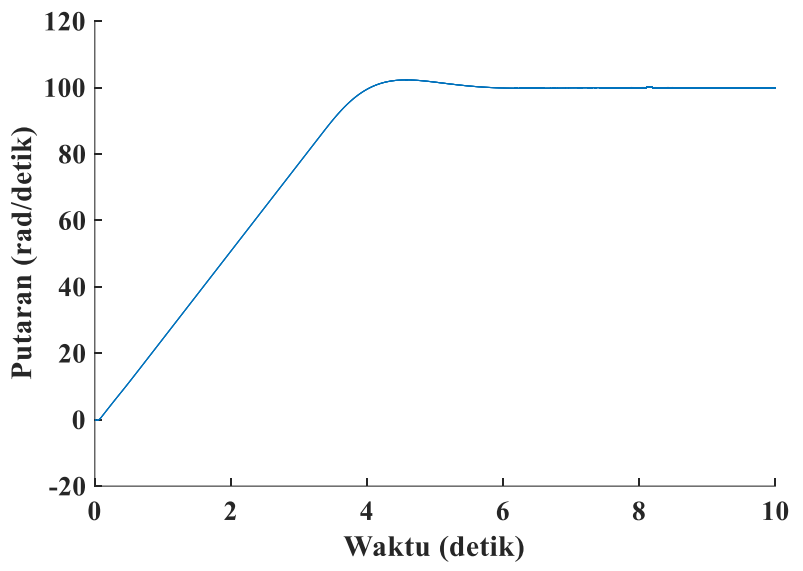

(a)

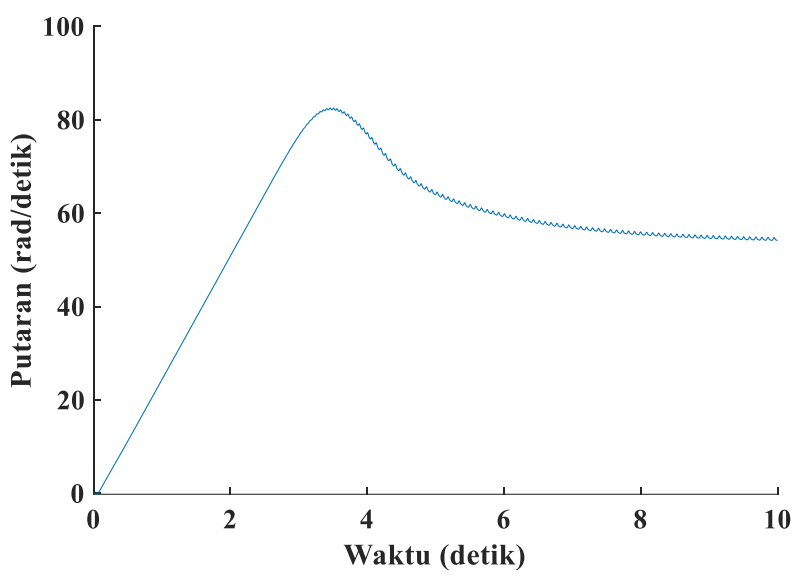

(b)

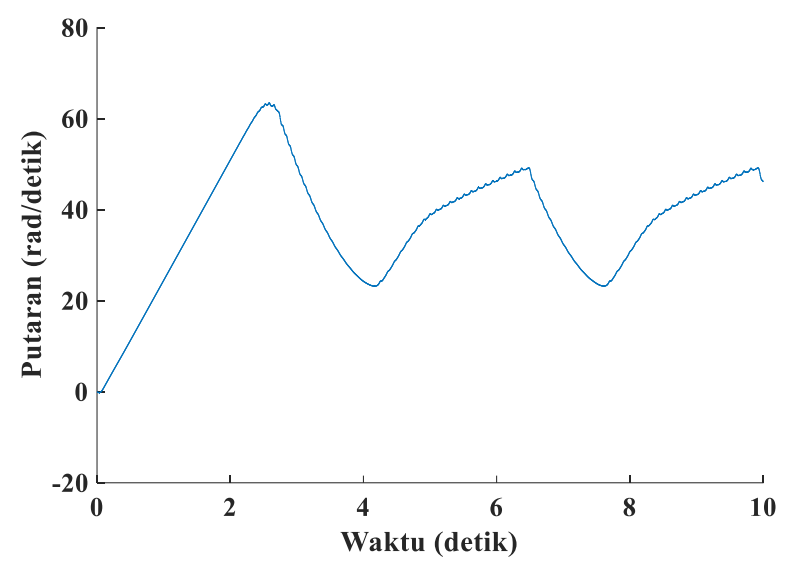

(c)

Gbr. 5 Putaran PMSM dengan nilai-nilai parameter $L_{s d}$ motor pada pengendali arus divariasi, (a) perubahan $300 \%$, (b) perubahan $500 \%$, (c) perubahan $600 \%$.

berosilasi pada putaran sekitar $40 \mathrm{rad} / \mathrm{s}$. Apabila delta $\Psi_{F}$ ditambah, tanggapan motor menjadi semakin buruk, seperti yang ditunjukkan pada Gbr. 7(c). Pada gambar tersebut, parameter $\Psi_{F}$ motor pada pengendali arus ditambah sebesar $15 \%$ sehingga menjadi 0,01495 V.s/rad. Tampak bahwa putaran motor menjadi tidak stabil. Motor bergetar di sekitar putaran $0 \mathrm{rad} / \mathrm{s}$. Dari pengujian ini tampak bahwa perubahan 


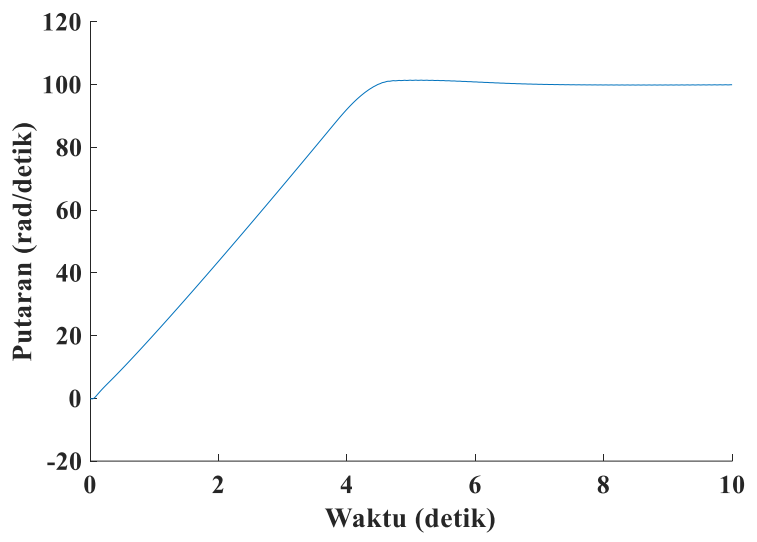

(a)

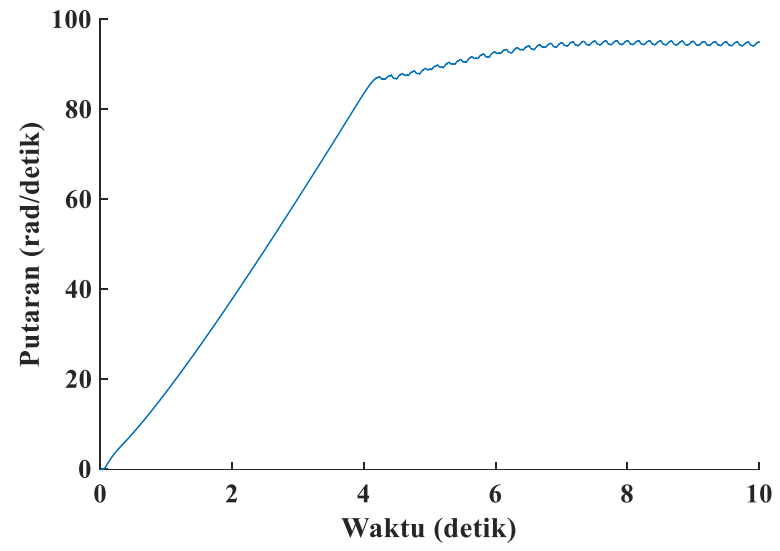

(b)

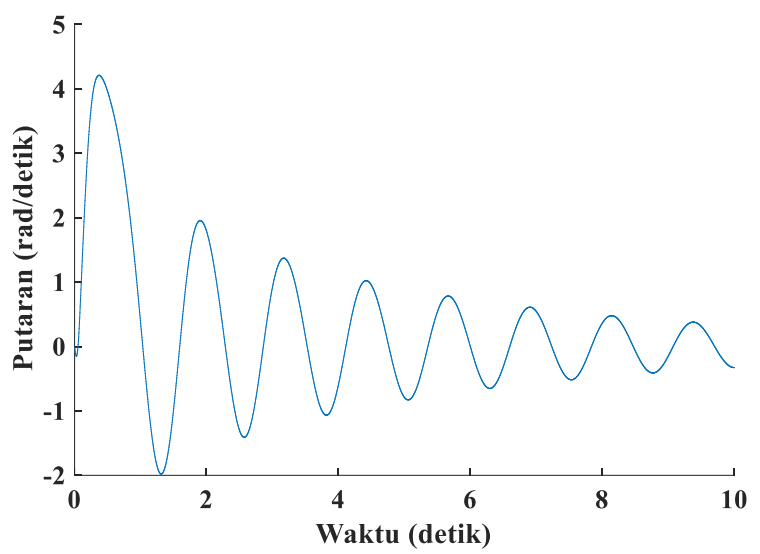

(c)

Gbr. 6 Putaran PMSM dengan nilai-nilai parameter $L_{s q}$ motor pada pengendali arus divariasi, (a) perubahan $200 \%$, (b) perubahan $300 \%$, (c) perubahan $500 \%$.

parameter $\Psi_{F} \geq 10 \%$ akan memengaruhi pengendalian putaran motor pada sistem kendali tanpa sensor putaran.

Dari hasil penelitian di atas, telah diperoleh hasil yang sesuai dengan hasil penelitian yang telah dilakukan sebelumnya [11]. Namun, dalam penelitian tersebut implementasi dilakukan pada motor induksi, bukan motor PMSM [11]. Dalam penelitian tersebut dinyatakan bahwa variasi nilai-nilai parameter akan menyebabkan kesalahan

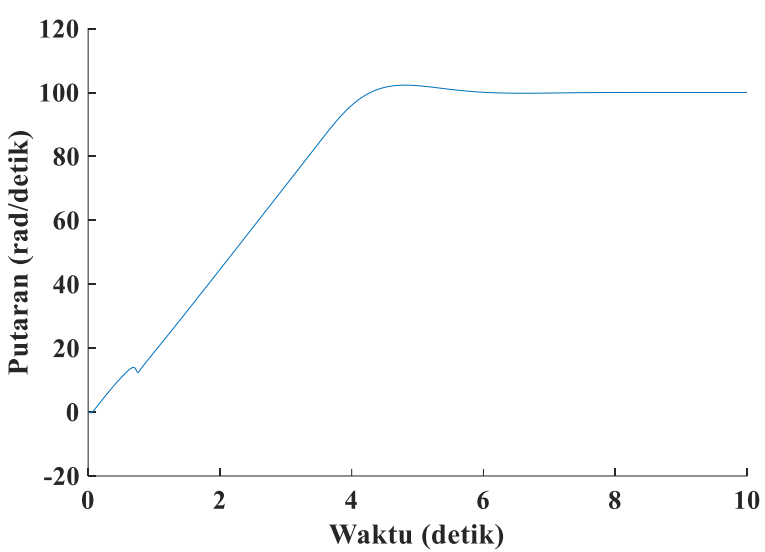

(a)

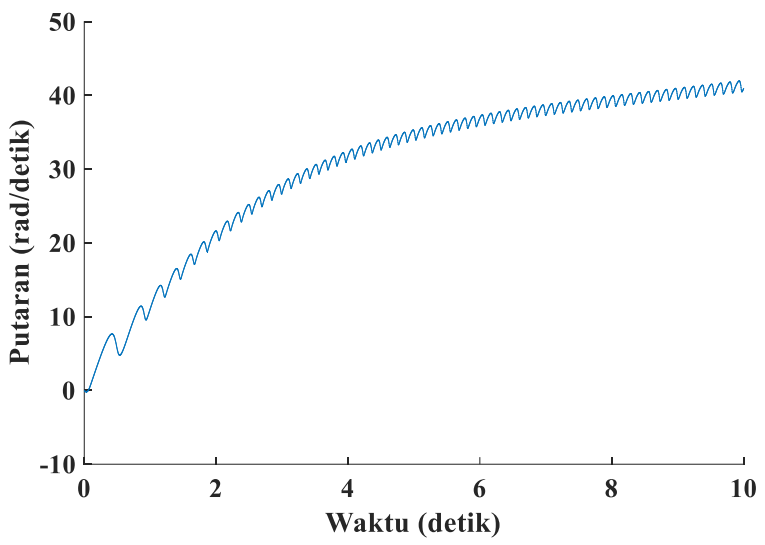

(b)

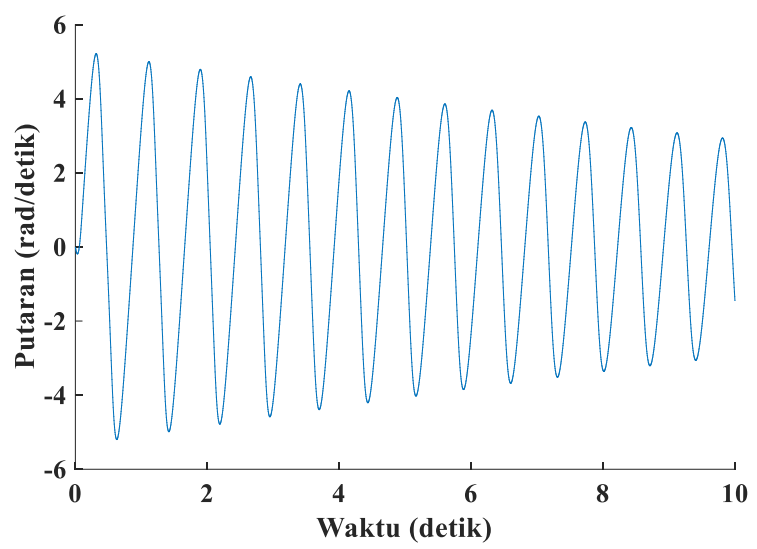

(c)

Gbr. 7 Putaran PMSM dengan nilai-nilai parameter $\Psi_{F}$ motor pada pengendali arus divariasi, (a) perubahan $5 \%$, (b) perubahan $10 \%$, (c) perubahan $15 \%$.

pada putaran motor. Namun, tidak dibahas besar persentase variasi perubahan masing-masing parameter motor yang akan memengaruhi pengendali putaran motor induksi tanpa sensor putaran/posisi [11].

\section{Kesimpulan}

Dari hasil pengujian sistem kendali tanpa sensor putaran, diketahui bahwa nilai parameter-parameter motor, yang 
meliputi nilai resistans, induktans, dan fluks magnetik, sangat memengaruhi kinerja sistem pengendali. Dari ketiga parameter tersebut, perubahan nilai resistans dan fluks magnetik paling memengaruhi sistem kendali. Putaran motor pada sistem pengendali tanpa sensor putaran tidak sama dengan putaran yang diinginkan jika perubahan nilai resistans $\geq 4 \%$ dan fluks magnetik $\geq 10 \%$. Nilai-nilai induktans akan berpengaruh jika perubahan induktans sangat besar, yaitu $L_{s d}$ $\geq 500 \%$ dan $L_{s q} \geq 300 \%$. Oleh karena itu, pengukuran parameter resistans dan fluks magnetik motor PMSM dalam sistem kendali tanpa sensor putaran sangat penting dilakukan secara tepat.

\section{REFERENSI}

[1] P. Vas, Sensorless Vector and Direct Torque Control, New York, USA: Oxford University Press, 1998.

[2] W.-H. Li, Z.-Y. Chen, dan W.-P. Cao, "Simulation Research on Optimization of Permanent Magnet Synchronous Motor Sensorless Vector Control Based on MRAS," Proc. 2012 Int. Conf. Wavelet Active Media Technol. and Inf. Proc. (ICWAMTIP), 2012, hal. 350-355.

[3] M. Yilmaz, "Limitations/Capabilities of Electric Machine Technologies and Modeling Approaches for Electric Motor Design and Analysis in Plug-In Electric Vehicle Applications," Renew. and Sust. Energy Rev., Vol. 52, hal. 80-99, 2015.

[4] B.W. Harini, F. Husnayain, A. Subiantoro, dan F. Yusivar, "A Synchronization Loss Detection Method for PMSM Speed Sensorless Control," J. Teknologi, Vol. 82, No. 4, hal.47-54 2020.

[5] Freescale Semiconductor, AN4680 Appl. Note, hal. 1-16.

[6] S. Ichikawa, M. Tomita, S. Doki, dan S. Okuma, "Sensorless Control of Permanent-Magnet Synchronous Motors using Online Parameter Identification Based on System Identification Theory," IEEE Trans. on Ind. Electron., Vol. 53, No. 2, hal. 363-372, 2006.
[7] L. Colombo, M.L. Corradini, A. Cristofaro, G. Ippoliti, dan G. Orlando, "An Embedded Strategy for Online Identification of PMSM Parameters and Sensorless Control," IEEE Trans. on Control Sys. Technol., Vol. 27, No. 6, hal. 2444-2452, 2019.

[8] X. Ma dan C. Bi, "A Technology for Online Parameter Identification of Permanent Magnet Synchronous Motor," CES Trans. on Elec. Mach. and Sys., Vol. 4, No. 3, hal. 237-242, 2020.

[9] Q. Wang, G. Wang, N. Zhao, G. Zhang, Q. Cui, dan D. Xu, "An Impedance Model-Based Multiparameter Identification Method of PMSM for Both Offline and Online Conditions," IEEE Trans. on Power Electron., Vol. 36, No. 1, hal. 727-738, 2021.

[10] P. Sun, Q. Ge, B. Zhang, dan X. Wang, "Sensorless Control Technique of PMSM based on RLS On-Line Parameter Identification," Proc. 2018 21st Int. Conf. on Elec. Mach. and Sys. (ICEMS), 2018, hal. 1670-1673.

[11] S. Yamamoto dan H. Hirahara, "Effect of Parameter Tuning on Driving Performance of a Universal-Sensorless-Vector-Controlled Closed-Slot Cage Induction Motor," Proc. 2019 22nd Int. Conf. on Elec. Mach. and Sys. (ICEMS), 2019, hal. 1-6.

[12] B.W. Harini, A. Subiantoro, dan F. Yusivar, "Study of Speed Sensorless Permanent Magnet Synchronous Motor (PMSM) Control Problem due to Braking During Steady State Condition," Proc. 2017 15th Int. Conf. on Qual. in Res. (QiR): Int. Symp. on Elec. and Comput. Eng., 2017, hal. 184-189.

[13] A.S. Mohamed, M.S. Zaky, A.Z. El Din, dan H.A. Yasin, "Comparative Study of Sensorless Control Methods of PMSM Drives," Innov. Sys. Design and Eng., Vol. 2, No. 5, hal. 44-66, 2011.

[14] G.D. Andreescu, "Position and Speed Sensorless Control of PMSM Drives based on Adaptive Observer," Proc. 8th European Conf. on Power Electron. and Appl. (EPE '99), 1999, hal. 1-10.

[15] A. Glumineau dan J. de León Morales, Sensorless AC Electric Motor Control, Cham, Switzerland: Springer, 2015.

[16] (2018) "Heuristic PID Tuning Procedures" [Online], https://control.com/textbook/process-dynamics-and-pid-controllertuning/heuristic-pid-tuning-procedures/, tanggal akses:12-Apr-2021. 